\title{
ХАРАКТЕРИСТИКА АДАПТИВНИХ ОЗНАК У МІЖСОРТОВИХ ГІБРИДІВ ПШЕНИЦІ М'ЯКОЇ ОЗИМОЇ В УМОВАХ-ПІВНІЧНО-СХІДНОГО ЛІСОСТЕПУ
}

Бакуменко Ольга Миколаївна кандидат сільськогосподарський наук Сумський національний аграрний університет, м. Суми, Україна ORCID: 0000-0003-1625-7401 lady.bakumenko88@gmail.com

Власенко Володимир Анатолійович доктор сільськогосподарський наук, професор Сумський національний аграрний університет, м. Суми, Україна ORCID: 0000-0002-5535-6747 vlasenkova@ukr.net

Осьмачко Олена Миколаївна кандидат сільськогосподарський наук Сумський національний аграрний університет, м. Суми, Україна ORCID: 0000-0003-0591-2650 lenaosmachko1978@ukr.net

Бурдуланюк Алла Олександрівна кандидат сільськогосподарський наук, доцент Сумський національний аграрний університет, м. Суми, Україна ORCID: 0000-0002-9258-7456 burdalla@ukr.net

Татаринова Валентина Іванівна кандидат сільськогосподарський наук, доцент Сумський національний аграрний університет, м. Суми, Україна ORCID: 0000-0001-5008-2276 tatarinovasnau@gmail.com

Деменко Віктор Михайлович кандидат сільськогосподарський наук, доцент Сумський національний аграрний університет, м. Суми, Україна ORCID: 0000-0002-8264-2802 vicmix64@ukr.net

Ємець Олександр Михайлович кандидат біологічних наук, доцент Сумський національний аграрний університет, м. Суми, Україна ORCID: 0000-0003-1228-1439 yemets_a@ukr.net

Сахошко Микола Миколайович кандидат сільськогосподарських наук, директор Сумської фрілії Українського інституту експертизи сортів рослин, м. Суми, Україна

ORCID: 0000-0001-8396-5737 sumy.dc@gmail.com

Башлай Аліна Григорівна аспірантка

Сумський національний аграрний університет, м. Суми, Україна

ORCID: 0000-0003-1133-4025 bashlay_alina@ukr.net

\section{Півторайко Віктор Володимирович} аспірант

Сумський національний аграрний університет, м. Суми, Україна ORCID: 0000-0002-0179-8646 pivtoraiko@gmail.com

У 2018-2019 році на дослідному полі Сумського національного аграрного університету проведено дослідження щодо формування елементів структури врожаю, стійкості до фрітопатогенів та інших адаптивних ознак 
міжсортовими гібридами пшениці озимої. Матеріалом досліджень слугували лінії (потомств $F_{4}$ та $F_{5}$ ), створені міжсортовим схрещуванням сортів пшениці озимої різного екологічного та генетичного походження з числа, занесених у різні роки до Державного реєстру сортів рослин придатних для поширення в Україні, зокрема з 1AL/1RS ma 1BL/1RS транслокаціями і без інтрогресованих компонентів. За тривалістю вегетаційного періоду від повних сходів до повного колосіння досліджувані зразки розподілились на дві групи - середньоранні та середньостиглі. Вегетаційний період у середньому складав 218 діб для $F_{4}$ та 216 - для $F_{5}$. Найнижчий цей показник (214 діб) виявився у гібридів п'ятого покоління, створених за участі сортів, які є носіями 1BL/1RS транслокації. Найдовший період вегетації зафріксований у цих же комбінаціях, проте - четвертого покоління. За рівнем зимостійкості усі групи гібридних комбінацій поступалися сорту-стандарту Подолянка, хоча і мали наближений до нього рівень показника (5,37-5,96 за 9-бальною шкалою). Гібридні потомства у польових умовах характеризувалися порівняно задовільною зимостійкістю. Перезимували на рівні стандарту з оцінкою 6 балів і вище 58,9 \% $\left(F_{4}\right)$ ma 64,3\% $\left(F_{5}\right)$ досліджуваних зразків. Спостерігається пряма залежність між: групою стиглості $\rightarrow$ висотою рослин $(r=0,95) \rightarrow$ стійкістю до перезимівлі $(r=0,87)$. Отже, чим коротший період вегетації генотипу, тим нижча висота рослин та бал перезимівлі рослин. У наших дослідах коефіцієнт кореляції близький до + 1, що свідчить про тісний прямолінійний кореляційний зв'язок (майже функціональний), між групою стиглості $\rightarrow$ висотою рослин $\rightarrow$ зимостійкістю. За стійкістю до листкових хвороб перевищували стандарт: до бурої іржі - 96,75 \% досліджуваних потомств; до борошнистої роси та септоріозу кращими за Подолянку виявилися 77 \%.

У досліджуваних генотипів урожайність варіювала від 225 до 891 г/м². Середнє популяційне значення ознаки для $F_{4}$ ma $F_{5}$ складало 640 г/м². Цей показник вказує на адаптивний оптимум урожайності культури, яку представляють новостворені потомства в $F_{4}$ ma $F_{5}$.

Ключові слова: пшениця м'яка озима, врожайність, резистентність, фрітопатогени, лінії, пшенично-житні транслокації.

DOI https://doi.org/10.32845/agrobio.2021.3.2

Вступ. Успіх вирощування сільськогосподарської продукції з підвищеною врожайністю залежить від сорту. Саме він, на думку А. А. Жученко (Zhuchenko, 2010), визначає основні вимоги до технологій вирощування рослини: продуктивність, енергоекономічність, екологічну безпечність, якість тощо. Для створення сортів пшениці озимої нового покоління необхідне попереднє вивчення генофонду вихідного матеріалу для підбору батьківських форм за комплексом цінних ознак, які відповідають вимогам сьогодення. Як свідчать результати досліджень ряд вчених вказують, що такі дослідження дають можливість розширювати еколого-географічну мінливість популяцій та визначити джерела цінних ознак для конкретних умови (Zhu et al., 2019; Wulff \& Jones, 2020; Xu et al., 2005; Wang et al. 2020; Waqar et al., 2018; Ward et al., 2008).

Успіх створення вихідного матеріалу пшениці озимої з адаптивними властивостями, стійкими до фітопатогенів та підвищеною врожайністю значною мірою залежить від цілеспрямованого пошуку джерел цих ознак. Виявлення та відбір цінних генотипів у селекційній роботі багато в чому залежить від біології відтворення рослин, характеристики успадкування ознак, гібридної генерації, екологічних умов та інших факторів (Osmachko et.al., 2020). Для ефективності проведення добору, необхідно виявити генотип за фенотипом, проте це обмежується тим, що більшість економічно цінних ознак є кількісними і залежать від факторів навколишнього середовища (Bakumenko \& Vlasenko, 2018).

Селекційна цінність гібридних комбінацій пшениці озимої визначається за результатами раннього тестування (починаючи з $\mathrm{F}_{1}$ ) і продовжується в наступних поколіннях з подальшим добором та відносно високою точністю виявлення кращих рослин (Bakumenko et.al., 2019).

Таким чином, наразі важливим чинником збільшення виробництва зерна та поліпшення його якості є постійне вдосконалення та створення нових сортів рослин, які здатні максимально використовувати біокліматичний потенціал полів та проявляти резистентні властивості до фітопатогенів. Отже, формування елементів структури врожаю, стійкості до фітопатогенів та адаптивних ознак міжсортовими гібридами $\left(F_{4}\right.$ та $\left.F_{5}\right)$ пшениці озимої не втрачає своєї актуальності та потребує подальших досліджень і доборів, які будуть упроваджені до селекційних установ України та сприятимуть створенню нових - перспективних сортів пшениці озимої.

Матеріали і методи досліджень. Дослідження проводили упродовж 2018-2019 вегетаційного року на дослідному полі Сумського національного аграрного університету (СумНАУ), що входить до північно-східної частини Лісостепу України. Ґрунти представлені на 70 \% чорноземами типовими малогумусними, чорноземами типовими вилуженими малогумусними важкосуглинковими і чорноземами типовими малогумусними слабозмитими середньосуглинковими. Середній уміст гумусу орних земель складає 4,1%. Орні землі мають високий уміст фосфору 15,1-15,4 мг на 100 г ґрунту і середній уміст рухомого калію 6,7-8,0 мг на 100 г ґрунту. Кислотність ґрунтового розчину близька до нейтральної - 5,9 рН (Masalitin, 2004). У цілому, можна стверджувати, що ґрунтові умови дослідного поля СумНАУ $є$ типовими для зони, що дозволяє реалізовувати генетично обумовлений потенціал продуктивності сортів пшениці озимої та визначити їх адаптивний потенціал. За попередні роки проведення досліджень на території СумНАУ відмічена нерівномірність опадів та значні коливання температури, порівняно з середніми багаторічними показниками. За період росту і розвитку пшениці м'якої озимої 2018-2019 вегетаційного року погодні умови можна охарактеризувати як помірно теплі з незначними опадами. Середньодобова (середньорічна) температура повітря сягнула $9,6^{\circ} \mathrm{C}$, що на $2,2^{\circ} \mathrm{C}$ вище багаторічного показника $\left(7,4^{\circ} \mathrm{C}\right)$. Абсолютний максимум іï $35,5^{\circ} \mathrm{C}$ відмічений у серпні місяці у першій декаді, мінімум - мінус $20{ }^{\circ} \mathrm{C}$ у першій декаді січня. Сума опадів за звітний 
2018-2019 сільськогосподарський рік становила 409 мм, що на 184 мм менше багаторічної норми (593 мм). Отже, погодні умови за вегетаційний періоди пшениці озимої відрізнялися від середньобагаторічних показників як за температурним режимом, так і кількістю атмосферних опадів та їх розподілом за місяцями.

Матеріалом досліджень слугували лінії (потомства $\mathrm{F}_{4}$ та $\mathrm{F}_{5}$ ) пшениці м'якої озимої створені міжсортовим схрещуванням сортів пшениці озимої різного генетичного та екологічного походження з числа генотипів, занесених у різні роки до Державного реєстру сортів рослин, придатних для поширення в Україні: Миронівська ранньостигла, Ремеслівна, Астет, Епоха одеська, Куяльник, Антонівка, Розкішна, Вільшана, Овідій, Поліська 90, Косоч, Василина, Досконала, Подолянка, Царівна та сорти-носії ПЖТ - Смуглянка, Веснянка Золотоколоса, (1AL/1RS) і Миронівська 65, Крижинка, Калинова (1BL/1RS). За їх участі були створені 28 реципрокних комбінацій (всього 56).

Польові досліди закладено 20 вересня, що є оптимальними строками для північно-східного Лісостепу України. При дослідженні для порівняння використовували сорт Подолянка (стандарт). Сівбу здійснювали в оптимальні строки ручною сівалкою СР-1 у 3-кратній повторності. Норма висіву потомства склала 5 млн. шт./ га. Площа ділянки $1 \mathrm{~m}^{2}$, попередник - гречка. Біометричний аналіз проводили за загальноприйнятими у кількісній селекції методами за середнім зразком 25-30 рослин кожного за такими ознаками: довжина кожного міжвузля, висота рослин, продуктивна кущистість, кількість колосків на колосі та довжина колоса, маса 1000 насінин, маса зерна з головного колоса та кількість зерен, маса зерна з рослини. Рослини збирали вручну в фазу повної стиглості зерна. Закладання дослідів, фенологічні спостереження, збирання і облік врожаю проводили згідно з методикою державного випробування сортів рослин на придатність до поширення в Україні (Volkodav, 2003; Rudenko et al., 1977). Морфологічну та господарську характеристику поколінь проводили за допомогою широкого уніфікованого класифікатора роду Triticum L. Для оцінки резистентності зразків до борошнистої роси і септоріозу застосовано модифіковану шкалу

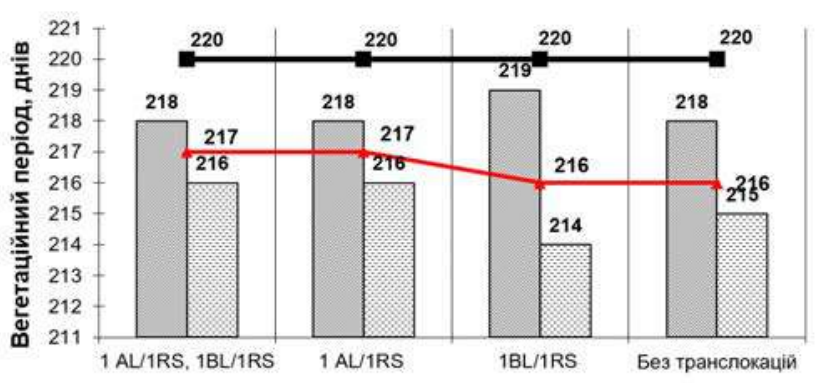

Група гібридів за походженням

$\square$ F4 ॠF5 $\quad$ - 5 -

Рис. 1. Розподіл потомств $F_{4}$ та $F_{5}$ за вегетаційним періодом залежно від походження
Саaрі і Прескота. Прояв стійкості до бурої іржі визначали за дев'яти бальною інтегрованою шкалою оцінки стійкості зернових колосових культур. Тобто були застосовані загальноприйняті методики, які широко апробовані при проведенні досліджень на генотипах пшениці озимої. Дослідження виконувалися з використанням польових, лабораторних і математично-статистичних методів (Dospehov, 1985; Vlasenko et al., 2020; Kovalenko et al., 2020). Результати експериментальних даних обробляли статистичними методами за програмою «Microsoft Excel2010» Windows XР на персональному комп'ютері.

Результати. Для визначення до якої групи стиглості відносяться гідридні комбінації було проведено підрахунок продовження вегетаційного періоду від фрази «повних сходів» до - «повного колосіння». Для порівняння, за стандарт, використовували середньостиглий сорт Подолянка (St) 3 вегетаційним періодом 220 днів. При цьому різниця вегетаційного періоду між групами досліджуваних зразків, що вивчалися, за стиглістю складала 4 доби. Вегетаційний період ультраранніх зразків вважали при продовження до 208 діб, ранніх - 209-212, середньоранніх - 213-216, середньостиглих - 217-220, середньопізніх - 221-224, пізніх - понад 224. За тривалістю вегетаційного періоду від повних сходів до повного колосіння досліджувані зразки розподілились на дві групи - середньоранні та середньостиглі (рис. 1).

У середньому вегетаційний період склав 218 діб для $\mathrm{F}_{4}$ та 216 - для $\mathrm{F}_{5}$. Найнижчий цей показник (214 діб) виявився у гібридів п'ятого покоління, створених за участі сортів носіїв 1BL/1RS транслокації. Найдовший період вегетації зафіксований у цих же комбінаціях, проте четвертого покоління. Загалом, істотної відмінності між досліджуваними гібридними групами за довжиною вегетаційного періоду не виявлено. Майже всі досліджувані зразки знаходяться на межі між середньоранніми та середньостиглими, що й пояснюється їх переходом у різних поколіннях на ранг вище або ранг нижче.

За рівнем зимостійкості (табл. 1) усі групи гібридних потомств поступалися сорту Подолянка, хоча і мали наближений до стандарту рівень показника (5,37-5,96 за 9-бальною шкалою).

При порівнянні окремих комбінацій зі стандартом виявились кращими за показником перезимівлі (понад 6 балів) потомства: створені за участі сортів з 1AL/1RS транслокацією - Смуглянка / Ремеслівна $\left(\mathrm{F}_{4}\right)$, Смуглянка / Миронівська ранньостигла $\left(\mathrm{F}_{4}\right)$, Золотоколоса / Куяльник $\left(\mathrm{F}_{4}\right)$, Золотоколоса / Вільшана $\left(\mathrm{F}_{4}\right.$ та $\left.\mathrm{F}_{5}\right)$, Золотоколоса / Антонівка $\left(\mathrm{F}_{4}\right.$ та $\left.\mathrm{F}_{5}\right)$, Антонівка / Золотоколоса $\left(\mathrm{F}_{4}\right.$ та $\left.\mathrm{F}_{5}\right)$, Золотоколоса / Косоч $\left(\mathrm{F}_{4}\right.$ та $\left.\mathrm{F}_{5}\right)$, Василина / Веснянка $\left(F_{5}\right)$. Поліська 90 / Веснянка $\left(F_{5}\right)$, Вільшана / Золотоколоса $\left(\mathrm{F}_{5}\right)$; з обома ПЖТ (1BL/1RS та 1AL/1RS) - Смуглянка / Крижинка $\left(\mathrm{F}_{4}\right)$, Золотоколоса / Миронівська $65\left(\mathrm{~F}_{4}\right)$, Веснянка / Калинова $\left(\mathrm{F}_{5}\right)$; без участі транслокацій - Розкішна / Ремеслівна $\left(\mathrm{F}_{4}\right)$, Розкішна / Миронівська ранньостигла $\left(\mathrm{F}_{4}\right)$, Розкішна / Епоха одеська $\left(\mathrm{F}_{4}\right)$. Загалом, гібридні комбінації у польових умовах СНАУ характеризувалися порівняно задовільною зимостійкістю. Перезимували на рівні стандарту з оцінкою 6 балів і вище 58,9\% $\left(\mathrm{F}_{4}\right)$ та 64,3 \% 
$\left(\mathrm{F}_{5}\right)$ досліджуваних зразків. Дослідженнями встановлено, що спостерігається пряма залежність між: групою стиглості $\rightarrow$ висотою рослин $(r=0,95) \rightarrow$ стійкістю до перезимівлі ( $r=0,87)$. Тобто, чим коротший період вегетації генотипу, тим нижча висота рослин та бал перезимівлі рослин. У наших дослідах коефіцієнт кореляції близький до + 1, що свідчить про тісний прямолінійний кореляційний зв'язок (майже функціональний), між групою стиглості $\rightarrow$ висотою рослин $\rightarrow$ зимостійкістю.

За допомогою оцінки стійкості проти хвороб та урожайності було визначено чинники, що впливали на прояв ознак. Виявлено різну норму реакції у генотипів залежно від походження (табл. 2). Проведений нами аналіз чотирьох груп гібридних комбінацій показує, що всі вони виявилися кращими за стандарт - на 1,33-1,75 бали для $\mathrm{F}_{4}$ та 1,22-2,01 бали для $\mathrm{F}_{5}$.

Сорт-стандарт Подолянка характеризувався вищесередньою стійкістю до листкових хвороб. Перевищували стандарт за стійкістю до бурої іржі 96,75 \% досліджуваних потомств: створені за схрещування носіїв 1AL/1RS та 1BL/1RS транслокацій одночасно - $100 \%$; $1 \mathrm{AL} / 1 \mathrm{RS}$ - $100 \%$; 1BL/1RS - $100 \%$; без інтрогресованих компонентів - $83 \%\left(\mathrm{~F}_{4}\right)$ та $91 \%\left(\mathrm{~F}_{5}\right)$. За стійкістю до борошнистої роси перевищували стандарт $77 \%$

Рівень зимостійкості та висоти рослин $\mathrm{F}_{4}$ та $\mathrm{F}_{5}$ залежно від їх походження

Таблиця 1 в умовах північно-східного Лісостепу України (СумНАУ)

\begin{tabular}{|c|c|c|c|c|c|c|c|c|c|c|c|}
\hline \multirow{3}{*}{ Група за походженням } & \multirow{3}{*}{ 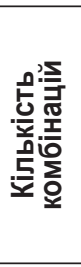 } & \multicolumn{4}{|c|}{$\begin{array}{l}\text { Кількість зразків пшениці } \\
\text { м'якої озимої (шт.) } \\
\text { за рівнем зимостійкості }\end{array}$} & \multirow{3}{*}{$\begin{array}{c}\bar{x} \\
\text { no грyпi, } \\
\text { бал }\end{array}$} & \multicolumn{5}{|c|}{ Висота рослин, см } \\
\hline & & \multirow{2}{*}{ 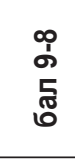 } & \multirow{2}{*}{$\begin{array}{l}\stackrel{0}{1} \\
\frac{1}{0} \\
0\end{array}$} & \multirow{2}{*}{$\begin{array}{l}\text { y } \\
\text { ñ } \\
\text { t్ } \\
0\end{array}$} & \multirow{2}{*}{ 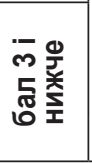 } & & \multirow{2}{*}{ 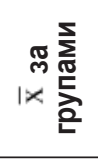 } & \multicolumn{2}{|c|}{$\begin{array}{c}\text { кількість зразків } \\
\text { за групами, шт }\end{array}$} & \multicolumn{2}{|c|}{ ліміти } \\
\hline & & & & & & & & HK & $\mathrm{CP}$ & $\min$ & $\max$ \\
\hline \multicolumn{12}{|c|}{$\mathrm{F}_{4}$} \\
\hline Подолянка, St & & & & & & 6,0 & 83,33 & & & & \\
\hline $1 \mathrm{AL} / 1 \mathrm{RS}, 1 \mathrm{BL} / 1 \mathrm{RS}$ & 6 & - & 3 & 3 & - & 5,8 & 83,16 & 3 & 3 & 75 & 90 \\
\hline $1 \mathrm{AL} / 1 \mathrm{RS}$ & 30 & 1 & 20 & 9 & - & 5,96 & 75,33 & 20 & 10 & 55 & 89 \\
\hline 1BL/1RS & 8 & - & 3 & 5 & - & 5,37 & 76,87 & 6 & 2 & 70 & 89 \\
\hline Без транслокацій & 12 & - & 6 & 5 & 1 & 5,41 & 74,91 & 9 & 3 & 58 & 95 \\
\hline \multicolumn{12}{|c|}{$\mathrm{F}_{5}$} \\
\hline $1 \mathrm{AL} / 1 \mathrm{RS}, 1 \mathrm{BL} / 1 \mathrm{RS}$ & 6 & - & 5 & 1 & - & 5,83 & 77,5 & 5 & 1 & 71 & 90 \\
\hline $1 \mathrm{AL} / 1 \mathrm{RS}$ & 30 & - & 17 & 13 & - & 5,80 & 76,56 & 24 & 6 & 68 & 93 \\
\hline 1BL/1RS & 8 & - & 3 & 5 & - & 5,25 & 79,62 & 3 & 5 & 64 & 92 \\
\hline Без транслокацій & 12 & - & 8 & 4 & - & 5,58 & 73,66 & 11 & 1 & 63 & 107 \\
\hline Примітка: тут і далі: & \multicolumn{11}{|c|}{$\begin{array}{c}\bar{x} \text { - середнє арифметичне; min - мінімальне, max - максимальне значення ознаки по досліду; } \\
\text { НК - напівкарлик 51-80 см; СР - середньорослий (81-110 см) }\end{array}$} \\
\hline
\end{tabular}

Таблиця 2

Характеристика рослин $\mathrm{F}_{4}$ та $\mathrm{F}_{5}$ пшениці м'якої озимої за стійкість до листкових хвороб та урожайністю в умовах СумНАУ

\begin{tabular}{|c|c|c|c|c|c|c|c|c|c|}
\hline \multirow{3}{*}{ Група за походженням } & \multirow{3}{*}{$\begin{array}{c}\text { Кількість } \\
\text { сортів } \\
\text { у групі, шт. }\end{array}$} & \multicolumn{4}{|c|}{ Стійкість проти хвороб, бал } & \multicolumn{4}{|c|}{ Урожайність, г/м² } \\
\hline & & \multirow{2}{*}{ 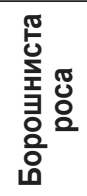 } & \multirow{2}{*}{ 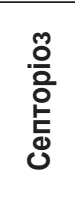 } & \multirow{2}{*}{ 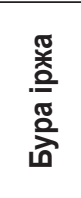 } & \multirow[b]{2}{*}{$\overline{\mathrm{x}}$} & \multirow[b]{2}{*}{$\overline{\mathrm{x}}$ за групами } & \multicolumn{2}{|c|}{ ліміти } & \multirow[b]{2}{*}{$\mathbf{R}$} \\
\hline & & & & & & & $\min$ & $\max$ & \\
\hline \multicolumn{10}{|c|}{$\mathrm{F}_{4}$} \\
\hline Подолянка (St) & - & 5 & 5,5 & 5,5 & 5,33 & 611 & \multicolumn{3}{|c|}{-} \\
\hline $1 \mathrm{AL} / 1 \mathrm{RS}, 1 \mathrm{BL} / 1 \mathrm{RS}$ & 6 & 6,35 & 6,79 & 7,67 & 6,94 & 652 & 384 & 820 & 436 \\
\hline $1 \mathrm{AL} / 1 \mathrm{RS}$ & 30 & 6,56 & 6,50 & 7,58 & 6,88 & 633 & 433 & 890 & 457 \\
\hline 1BL/1RS & 8 & 6,65 & 6,83 & 7,77 & 7,08 & 606 & 395 & 900 & 505 \\
\hline Без транслокацій & 12 & 6,59 & 6,22 & 7,16 & 6,66 & 657 & 225 & 891 & 666 \\
\hline Хд & 56 & 6,54 & 6,59 & 7,55 & 6,89 & 637 & 359 & 875 & 516 \\
\hline \multicolumn{10}{|c|}{$F_{5}$} \\
\hline $1 \mathrm{AL} / 1 \mathrm{RS}, 1 \mathrm{BL} / 1 \mathrm{RS}$ & 6 & 6,41 & 7,34 & 7,63 & 7,13 & 661 & 459 & 848 & 389 \\
\hline $1 \mathrm{AL} / 1 \mathrm{RS}$ & 30 & 6,78 & 7,30 & 7,25 & 7,11 & 633 & 432 & 813 & 381 \\
\hline 1BL/1RS & 8 & 6,81 & 7,74 & 7,46 & 7,34 & 615 & 448 & 834 & 386 \\
\hline Без транслокацій & 12 & 6,23 & 6,33 & 7,08 & 6,55 & 651 & 341 & 844 & 503 \\
\hline $\mathrm{Xg}_{\mathrm{g}}$ & 56 & 6,56 & 7,18 & 7,36 & 7,03 & 640 & 420 & 835 & 415 \\
\hline
\end{tabular}

Примітка: Хठ - середнє у досліді; $R$ - розмах варіювання ознаки 
досліджуваних генотипів, з них: створені за схрещування носіїв 1 AL/1RS та 1BL/1RS транслокацій - $33 \%$ $\left(\mathrm{F}_{4}\right)$ та $50 \%\left(\mathrm{~F}_{5}\right) ; 1 \mathrm{AL} / 1 \mathrm{RS}-73 \%\left(\mathrm{~F}_{4}\right)$ та $83 \%\left(\mathrm{~F}_{5}\right)$; 1BL/1RS - $100 \%$; без інтрогресованих компонентів $83 \%\left(\mathrm{~F}_{4}\right)$ та $91 \%\left(\mathrm{~F}_{5}\right)$. За стійкістю проти септоріозу кращими за Подолянку виявилися 77 \% досліджуваних генотипів $F_{4}$ та $F_{5}$ : створені за схрещування носіїв $1 \mathrm{AL} / 1 \mathrm{RS}$ та $1 \mathrm{BL} / 1 \mathrm{RS}$ транслокацій - $50 \%\left(\mathrm{~F}_{4}\right)$ та $83 \%$ $\left(\mathrm{F}_{5}\right) ; 1 \mathrm{AL} / 1 \mathrm{RS}-87 \%\left(\mathrm{~F}_{4}\right)$ та $97 \%\left(\mathrm{~F}_{5}\right) ; 1 \mathrm{BL} / 1 \mathrm{RS}-62 \%$ $\left(F_{4}\right)$ та $97 \%\left(F_{5}\right)$; без інтрогресованих компонентів $83 \%\left(\mathrm{~F}_{4}\right)$ та $58 \%\left(\mathrm{~F}_{5}\right)$.

Для сучасної селекції найбільшу значущість мають генотипи з високою стійкістю, або імунні до комплексу хвороб листя. Зазначаємо, що більшість новостворених доборів характеризувалися комплексною стійкістю до хвороб листя та зарекомендували себе краще за стандарт - Подолянку. Також важливим фактом $€$ те, що комбінації створені за участі сортів носіїв ПЖТ виявилися кращі не лише за стандарт, а й за гібриди, які створені без інтрогресованих компонентів. Вірогідно, це зумовлено тим, що носії пшенично-житніх транслокацій володіють підвищеною стійкістю до патогенів рослин і шкідників - переносників ряду вірусних хвороб. Гени стійкості в гібридних потомствах з їхньою участю успадковуються завдяки наявності житнього компонента хромосоми 1RS.

У досліджуваних генотипів урожайність варіювала від 225 до 891 г/M². Середнє популяційне значення ознаки

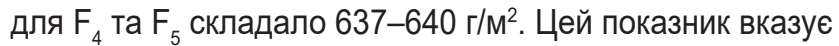
на адаптивний оптимум урожайності культури, яку представляють новостворені потомства в $\mathrm{F}_{4}$ та $\mathrm{F}_{5}$ в умовах північно-східного Лісостепу України. Перевищення його вказує на кращий рівень адаптивності генотипу в умовах досліджень, оскільки більше наближається до більш повної реалізації рівня генетичного потенціалу.

Необхідно відмітити, що за урожайністю кращими

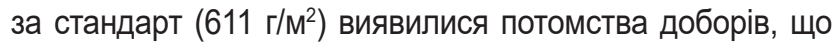
створені як за участі сортів носіїв 1AL/1RS транслокації

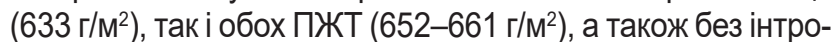
гресованих компонентів (651-657 т/га). Лінії, що створені за участі сортів носіїв 1BL/1RS транслокації мали показник урожайності на рівні стандарту - 601-615 г/м². Отримані результати врожайності вказують на те, що селекційний матеріал $\mathrm{F}_{4}$ та $\mathrm{F}_{5}$ характеризується доволі високим рівнем потенційної урожайності. Розмах варіювання за урожайністю у середині груп досліджень становив 436-666 т/га для $\mathrm{F}_{4}$ та 381-505 г/M² для $\mathrm{F}_{5}$. Найменший його показник спостерігався у потомств, створених за участі сортів-носіїв 1AL/1RS транслокації. Найбільший розмах варіювання досліджуваної ознаки заффіксовано в групі комбінацій, створених без інтрогресованих компонентів.

Обговорення. Важливим завданням селекції будьякої зернової культури є створення сортів, що володіють екологічною пластичністю, високою продуктивністю і якістю зерна, стійкістю до абіотичних і біотичних стресів. Наразі час селекція зернових культур досягла значних успіхів при створенні високопродуктивних сортів. Нові сорти успішно конкурують за врожайністю з традиційними зерновими культурами, такими як пше- ниця, жито і ячмінь (Gordinskaya et al., 2020; Naymushina \& Yaichkin, 2018).

Проте, зазначається, що істотним недоліком високоефективних інтрогресивних ліній $€$ відсутність стабільності врожайності в різних умовах (Motsnyi, 2014). Зазначене, як правило, властиве похідним екологічно віддалених гібридів. Очевидно, що ця модель поширюється на міжвидову гібридизацію, яка певною мірою також є екологічно віддаленою (Motsniy et al., 2021).

Варто зауважити, що в нашому дослідженні отримані результати вказують на те, що селекційний матеріал $\mathrm{F}_{4}$ та $\mathrm{F}_{5}$ характеризується доволі високим рівнем потенційної урожайності та порівняно високою її стабільністю. Водночас, урожайності пшениці вже загрожує глобальна зміна клімату (Porter et al. 2019), тим самим знижуючи частину приросту врожаю отриману від активної роботи селекціонерів (створення інтенсивних сортів) та інших технологічних досягнень (Lobell et al., 2011). Передбачається до середини цього століття підвищення температури до 2,0 ${ }^{\circ} \mathrm{C}$ (Ceglar et al., 2019). У більшості південних та центральних частин Європи під час вегетаційногоо періоду вирощування сільськогосподарських культур, включаючи весну та літо, буде сухіше та тепліше. Це збільшить ризик екстремальних погодних явищ, таких як спека та посуха. Поряд з цим продуктивність сільськогосподарських культур потрібно постійно підвищувати, особливо підвищуючи значимість селекційних досягнень, що має сприяти стабільній урожайності (Miedaner, 2018). Створення та розмноження селекційного матеріалу резистентного до комплексу хвороб та адаптивними властивостями (Li et al., 2020) є надзвичайно важливим серед інших властивостей рослин (наприклад - ефективність використання води, ефективність використання азоту тощо) для досягнення стабільної врожайності (Chapman et al., 2012). Тому селекція рослин повинна враховувати як абіотичні (наприклад - спека, посуха, перезволоження, кислотність), так і біотичні стреси (Ceccarelli et al., 2010), включаючи, наприклад, комах-шкідників та патогенні мікроорганізми, такі як бактерії, фрітоплазми, віруси, гриби, ооміцети, та нематоди. Використання стійких або толерантних сортів $€$ дешевим, екологічно чистим та ефективним методом захисту рослин (Juroszek \& Tiedemann, 2011). Умови навколишнього середовища можуть впливати на стійкість до хвороб (Duveiller et al., 2007), внаслідок чого рослина-господар може бути ослаблена, а патоген може бути зміцнений та впливати на функцію певного гена стійкості. Наприклад, стійкість до захворювання може залежати від температури та інтенсивності світла (Chakraborty, 2013). Крім того, недостатня кількість вологи, посуха також має вплив на резистентність сорту (Bidzinski et al., 2016).

Щодо кількісної резистентності виявлено, що стійкість генотипів може сильно варіювати через вплив специфічних умов середовища вирощування культури. Отже, екологічна стабільність, адаптивність і резистентність мають вирішальне значення при створенні сорту та формуванні ним стабільних і додатково вказує на актуальність та необхідність проведення селекційних досліджень міжсортовими гібридами $\left(\mathrm{F}_{4}\right.$ та $\left.\mathrm{F}_{5}\right)$ пшениці озимої та відбір кращих зразків з підвищеною адап- 
тивністю, врожайністю та стійкості до фрітопатогенів. У цьому контексті вбачаємо практичну цінність створених нами ліній з груповою стійкістю до хвороб, що також має значне значення для розвитку адаптивної селекції та формування адаптивних ознак, які забезпечать більш повну реалізацію генетичного потенціалу.

Висновки. За результатами дослідження виявлено, що вегетаційний період склав 218 діб для $\mathrm{F}_{4}$ та 216 - для $\mathrm{F}_{5}$. Найнижчий цей показник (214 діб) виявився у потомств п'ятого покоління, створених за участі сортів носіїв 1BL/1RS транслокації. Найдовший період вегетації зафіксований у цих же комбінаціях, проте четвертого покоління.

Кращий показником перезимівлі (понад 6 балів) характеризувалися потомства: створені за участі сортів з 1AL/1RS транслокацією - Смуглянка / Ремеслівна $\left(\mathrm{F}_{4}\right)$, Смуглянка / Миронівська ранньостигла $\left(\mathrm{F}_{4}\right)$, Золотоколоса / Куяльник $\left(\mathrm{F}_{4}\right)$, Золотоколоса / Вільшана $\left(\mathrm{F}_{4}\right.$ та $\left.\mathrm{F}_{5}\right)$, Золотоколоса / Антонівка $\left(\mathrm{F}_{4}\right.$ та $\left.\mathrm{F}_{5}\right)$, Антонівка / Золотоколоса $\left(\mathrm{F}_{4}\right.$ та $\left.\mathrm{F}_{5}\right)$, Золотоколоса / Косоч $\left(\mathrm{F}_{4}\right.$ та $\left.\mathrm{F}_{5}\right)$, Василина / Веснянка $\left(F_{5}\right)$. Поліська $90 /$ Веснянка $\left(F_{5}\right)$, Вільшана / Золотоколоса $\left(\mathrm{F}_{5}\right)$; з обома ПЖТ (1BL/1RS та 1AL/1RS) - Смуглянка / Крижинка $\left(\mathrm{F}_{4}\right)$, Золотоколоса / Миронівська $65\left(\mathrm{~F}_{4}\right)$, Веснянка / Калинова $\left(\mathrm{F}_{5}\right)$; без участі транслокацій - Розкішна / Ремеслівна $\left(\mathrm{F}_{4}\right)$, Розкішна / Миронівська ранньостигла $\left(\mathrm{F}_{4}\right)$, Розкішна / Епоха одеська $\left(\mathrm{F}_{4}\right)$.

Перевищували стандарт за стійкістю до бурої іржі 96,75 \% досліджуваних комбінацій $F_{4}$ та $F_{5}$ потомства: створені за схрещування носіїв 1AL/1RS та 1BL/1RS транслокацій - $100 \%$; 1AL/1RS - $100 \%$; 1BL/1RS $100 \%$; без інтрогресованих компонентів - $83 \%\left(F_{4}\right)$ та $91 \%$ $\left(\mathrm{F}_{5}\right)$. За стійкістю до борошнистої роси перевищували стандарт 77 \% досліджуваних генотипів, з них: створені за схрещування носіїв 1 AL/1RS та 1BL/1RS транслокацій $33 \%\left(\mathrm{~F}_{4}\right)$ та $50 \%\left(\mathrm{~F}_{5}\right) ; 1 \mathrm{AL} / 1 \mathrm{RS}-73 \%\left(\mathrm{~F}_{4}\right)$ та $83 \%\left(\mathrm{~F}_{5}\right)$; 1BL/1RS - $100 \%$; без інтрогресованих компонентів - $83 \%$ $\left(\mathrm{F}_{4}\right)$ та $91 \%\left(\mathrm{~F}_{5}\right)$. За стійкістю проти септоріозу кращими за Подолянку виявилися 77 \% досліджуваних генотипів $F_{4}$ та $F_{5}$ : створені за схрещування носіїв 1 AL/1RS та 1BL/1RS транслокацій - $50 \%\left(\mathrm{~F}_{4}\right)$ та $83 \%\left(\mathrm{~F}_{5}\right) ; 1 \mathrm{AL} / 1 \mathrm{RS}-$ $87 \%\left(\mathrm{~F}_{4}\right)$ та $97 \%\left(\mathrm{~F}_{5}\right) ; 1 \mathrm{BL} / 1 \mathrm{RS}-62 \%\left(\mathrm{~F}_{4}\right)$ та $97 \%\left(\mathrm{~F}_{5}\right) ;$ без інтрогресованих компонентів - $83 \%\left(\mathrm{~F}_{4}\right)$ та $58 \%\left(\mathrm{~F}_{5}\right)$.

Урожайність у досліджуваних генотипів варіювала від 225 до 891 г/м². Середнє популяційне значення

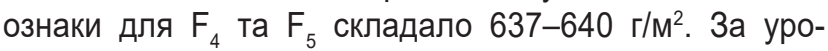
жайністю кращими за стандарт (611 т/га) виявилися потомства доборів, що створені як за участі сортів носіїв 1AL/1RS транслокації (633 г/м²), так і обох ПЖТ

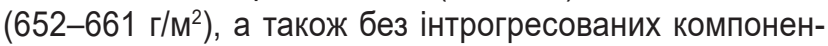

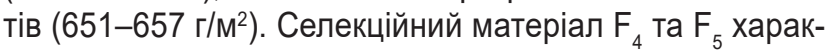
теризується доволі високим рівнем реалізації потенційної урожайності, що передбачає практичну значимість для подальшої роботи.

Дослідження проводяться згідно Державного замовлення «Відбір перспективних ліній пшениці м'якої для створення сортів з груповою стійкістю до хвороб» (номер державної реєстрації теми: 0119U102849) за підтримки Міністерства освіти і науки України.

\section{Бібліографічні посилання:}

1. Bakumenko, O. M., \& Vlasenko, V. A. (2018). Effects of wheat-rye translocations on the combinatorial ability of winter wheat varieties Selection and seed production, 113, 8-17 [Electronic resource]. Access mode: http://repo.snau.edu.ua/handle/123456789/7122 (in Ukrainian).

2. Bakumenko, O. M., Osmachko, O. M., \& Vlasenko, V. A. (2019). Combinative ability of winter wheat cultivars Kryzhynka and Smuhlianka: monograph, Sumy: Mriia, 194 [Electronic resource] Access mode: http://repo.snau.edu.ua/handle/123456789/7298 (in Ukrainian).

3. Bidzinski, P., Ballini, E., Ducasse, A., Michel, C., Zuluga, P., Genga, A., Chiozzotto, R., \& Morel, J.B. (2016). Transcriptional basis of droughtinduced susceptibility to the rice blast fungus Magnaporthe oryzae. Front Plant Sci, 7, 1558. doi: 10.3389/fpls. 2016.01558.

4. Ceccarelli, S., Grando, S., Maatougui, M., Michael, M., Slash, M., Haghparast, R., Rahmanian, M., Taheri, A., Al-Yassin, A., Benbelkacem, A., Labdi, M., Mimoun, H., \& Nachit, M. (2010). Plant breeding and climate changes. J Agric Sci, 148, 627-637. doi: 10.1017/S0021859610000651.

5. Ceglar, A., Zampieri, M., Toreti, A., \& Dentener, F. (2019). Observed northward migration of agro-climate zones in Europe will further accelerate under climate change, Earth's Future, 7, 1088-1101. doi: 10.1029/2019EF001178.

6. Chakraborty, S. (2013). Migrate or evolve: options for plant pathogens under climate change. Glob Change Biol, 19, 1985-2000. doi: 10.1111/gcb.12205.

7. Chapman, S. C., Chakraborty, S., Dreccer, M. F., \& Howden, S. M. (2012). Plant adaptation to climate change - opportunities and priorities in breeding. Crop Pasture Sci, 6, 251-268. doi: 10.1071/ CP11303.

8. Dospehov, B. A. (1985). Metodika polevogo opyita, M.: Agropromizdat, 352. (in Russian).

9. Duveiller, E., Singh, R. P., \& Nicol, J. M. (2007). The challenges of maintaining wheat productivity: pests, diseases, and potential epidemics. Euphytica, 157, 417-430. doi: 10.1007/ s10681-007-9380-z.

10. Gordinskaya, E.A., Krokhmal, A.V., Grabovets, A.I., Barulina, N.I., \& Biryukova, O. V. (2020). Characteristics of the biological potential of winter triticale varieties. Scientific and production journal "Legumes and cereals", 4 (36), 158-164. (in Russian). doi: 10.24412/2309-348X-2021-2-158-164

11. Juroszek, P., \& Tiedemann, A. (2011). Potential strategies and future requirements for plant disease management under a changing climate. Plant Pathol, 60, 100-112. doi: 10.1111/j.1365-3059.2010.02410.x.

12. Kovalenko, I. M., Kandyba, N. M., Rozhkova, T. O., Kryuchko, L. V., Bakumenko, O. M., Kovalenko, V. M., Vereshchagin, I.V., \& Danilchenko, O.M. (2020). Laboratory work in agronomy: a textbook, Sumy, 293. [Electronic resource]. Access mode: http://repo.snau.edu.ua/bitstream/123456789/7677/1/1.pdf (in Ukrainian).

13. Li, W., Deng, Y., Ning, Y., He, Z., \& Wang, G.L. (2020). Exploiting broadspectrum disease resistance in crops: from molecular dissection to breeding. Annual Rev Plant Biol, 71, 575-603. doi: 10.1146/annurev-arplant-010720-022215.

14. Lobell, D.B., Schlenker, W., \& Costa-Roberts, J. (2011). Climate trends and global crop production since 1980. Science 333, 616-620. doi: 10.1126/science.1204531.

15. Masalitin, P. V. (2004). Ahrokhimichnyi ta ekonomichnyi stan ornykh zemel Sumskoi oblasti. Naukovo-obgruntovana systema vedennia silskoho hospodarstva Sumskoi oblasti, Sumy : VAT «SOD», Kozatskyi val, 77-92 (in Ukrainian). 
16. Metodyka Derzhavnoho vyprobuvannia sortiv roslyn na prydatnist do poshyrennia $v$ Ukraini: zahalna chastyna. Okhorona prav na sorty roslyn : ofitsiinyi biul. / Hol. red. Volkodav, V. V., (2003). Alefa, Kyiv, 1(3), 106 (in Ukrainian).

17. Miedaner, T. (2018). Wo hat der Anbau seine Grenzen? [Maize - Where are the limits of cultivation? in German], Innovations-Magazin Mais, 3, 22-25.

18. Motsnyi, I.I., Narhan, T.P., Lyfenko, S.Ph. \& Yerynyak, N.I. (2014). Involvement of introgression lines for winter bread wheat breeding, Bulletin of Kharkiv National Agrarian University. Series: Biology, 31, 1, 79-90 (in Ukrainian).

19. Motsniy, I.I., Molodchenkova, O.O., Smertenko, A.P., Mishchenko, L.T., Kryvenko, A.I. \& Solomonov, R.V. (2021). Selection evaluation of introgressive lines of soft winter wheat with signs of resistance to phytopathogens. Plant Archives, 21, 486-498. Access mode: https://doi.org/10.51470/PLANTARCHIVES.2021.v21.S1.076.

20. Naymushina, A. Yu., \& Yaichkin, V. N. (2018). Vliyaniye sorta na urozhaynost' i kachestvo zerna yarovoy pshenitsy $v$ usloviyakh Orenburgskogo Predural'ya [The influence of the variety on the yield and grain quality of spring wheat in the conditions of the Orenburg Cis-Urals]. Bulletin of the Orenburg State Agrarian University, 3(71), 45-48 (in Russian).

21. Osmachko, O. M., Bakumenko, O. M., \& Vlasenko, V. A. (2020). Creation of bread winter wheat initional material of leaf diseases resistance in the conditions north-east Foreststeppe: Monograph, Sumy, 214.

22. Rudenko, M. I., Shitova, I. P., Korneychuk, V. A. (1977). Metodicheskie ukazaniya po izucheniyu mirovoy kolektsii pshenitsyi: Izdanie trete, pererabotannoe. L., 28 (in Russian).

23. Vlasenko, V. A., O. M., Osmachko, \& O. M., Bakumenko, (2020). Methodical recommendations for the selection of wheat lines with group resistance to diseases that are carriers of wheat-rye translocations. Sumy National Agrarian University, Sumy, 154 (in Ukrainian).

24. Waqar, A., Khattak, S. H., Begum, S., Rehman, T., Shehzad, A., Ajmal, A., et al. (2018). Stripe rust: A 1688 review of the disease, Yr genes and its molecular markers. Sarhad J. Agric., 34, 188-201. doi: 10.17582/journal.sja/2018/34.1.188.201

25. Wang, H., Sun, S., Ge, W., Zhao, L., Hou, B., Wang, K., et al. (2020). Horizontal gene transfer of Fhb7 from fungus underlies Fusarium head blight resistance in wheat. Science 368, eaba5435. doi: 10.1126/science.aba5435

26. Ward, T. J., Clear, R. M., Rooney, A. P., O'Donnell, K., Gaba, D., Patrick, S., et al. (2008). An adaptive evolutionary shift in Fusarium head blight pathogen populations is driving the rapid spread of more toxigenic Fusarium graminearum in North America. Fungal Genet. Biol., 45, 473-484. doi: 10.1016/j.fgb.2007.10.003].

27. Wulff, B. B. H., \& Jones, J. D. G. (2020). Breeding a fungal gene into wheat. Science, 368, 822-823. doi: 10.1126/ science.311.5769.1843b

28. Xu, X., Bai, G., Carver, B. F., Shaner, G. E., \& Hunger, R. M. (2005). Molecular characterization of slow leaf-rusting resistance in wheat. Crop Sci. 45, 758-765. doi: 10.2135/cropsci2005.0758

29. Zhu, Z., Hao, Y., Mergoum, M., Bai, G., Humphreys, G., Cloutier, S., et al. (2019). Breeding wheat for resistance to Fusarium head blight in the Global North: China, USA, and Canada.Crop J., 7, 730-738. doi: 10.1016/j.cj.2019.06.003

30. Zhuchenko, A. A. (2010). Adaptive strategy for the development of agriculture in Russia in the XXI century (ecological and genetic foundations). Theory and Practice, Agrorus, Moscow, 1053. (in Russian).

Bakumenko O. M., PhD (Agricultural Sciences), Sumy National Agrarian University, Sumy, Ukraine

Vlasenko V. A., Doctor (Agricultural Sciences), Professor, Sumy National Agrarian University, Sumy, Ukraine

Osmachko O. M., PhD (Agricultural Sciences), Sumy National Agrarian University, Sumy, Ukraine

Burdulaniuk A. O., PhD (Agricultural Sciences), Associate Professor, Sumy National Agrarian University, Sumy, Ukraine

Tatarynova V. I., PhD (Agricultural Sciences), Associate Professor, Sumy National Agrarian University, Sumy, Ukraine

Demenko V. M., PhD (Agricultural Sciences), Associate Professor, Sumy National Agrarian University, Sumy, Ukraine

Yemets O. M., PhD (Agricultural Sciences), Professor, Sumy National Agrarian University, Sumy, Ukraine

Sakhoshko M. M., PhD (Agricultural Sciences), Director of the Sumy branch of the Ukrainian Institute of Plant Variety Examination, Sumy, Ukraine

Bashlai A. H., PhD Student, Sumy National Agrarian University, Sumy, Ukraine

Pivtoraiko V. V., PhD Student, Sumy National Agrarian University, Sumy, Ukraine

Characteristic of adaptive traits in intervariety hybrids of bread winter wheat in conditions of north-eastern forest steppe

In 2018-2019, the research field of Sumy National Agrarian University conducted a study on the formation of elements of crop structure, resistance to phytopathogens and others adaptive traits of interspecific hybrids of winter wheat. The research material was lines (offspring $F_{4}$ and $F_{5}$ ), created by inter-varietal crossing of winter wheat varieties of different ecological and genetic origin from the number entered in different years in the State Register of plant varieties suitable for distribution in Ukraine, in particular with 1AL/1RS and 1BL/1RS translocations and without introgressed components. According to the duration of the vegetation period from full germination to full earing, the studied samples were divided into two groups medium-early and medium-ripe. The growing season averaged 218 days for $F_{4}$ and 216 for $F_{5}$. The lowest rate (214 days) was found in fifth-generation hybrids created with varieties that are carriers of $1 B L / 1 R S$ translocation. The longest growing season is recorded in the same combinations, however - the fourth generation. In terms of winter hardiness, all groups of hybrid combinations were inferior to the Podolyanka standard variety, although they had a level close to it (5.37-5.96 on a 9-point scale). Hybrid offspring's in the field were characterized by relatively satisfactory winter hardiness. Overwintered at the standard level with a score of 6 points and above $58.9 \%\left(F_{4}\right)$ and $64.3 \%\left(F_{5}\right)$ of the tested samples. There is a direct relationship between: maturity group $\rightarrow$ plant height $(r=0.95) \rightarrow$ resistance to overwintering $(r=0.87)$. That is, the shorter the growing season of the genotype, the lower the height of plants and the score of overwintering plants. In our experiments, 
the correlation coefficient is close to +1 , which indicates a close rectilinear correlation (almost functional) between the group of maturity $\rightarrow$ plant height $\rightarrow$ winter hardiness. Resistance to leaf diseases exceeded the standard: to brown rust $-96.75 \%$ of the studied offspring; before powdery mildew and septoria $77 \%$ were better than Podolyanka.

In the studied genotypes, the yield varied from 225 to $891 \mathrm{~g} / \mathrm{m}^{2}$. The average population value of the trait for $F_{4}$ and $F_{5}$ was $640 \mathrm{~g} / \mathrm{m}^{2}$. This indicator indicates the adaptive optimum of crop yield, which is represented by newly created offspring in $\mathrm{F}_{4}$ and $F_{5}$.

Key words: bread winter wheat, yield, resistance, phytopathogens, lines, wheat-rye translocations. 